\title{
The forecast for podcasts
}

\section{Sunny skies but not necessarily with clear visibility}

\author{
Ted M. Burns, MD
}

It seems like the report of an important advance in neurology is a weekly occurrence. For many of us, the potential and rapid progress of neurology was one of the major attractions for our choosing this career. But for residents and fellows, already busy with personal lives and the fundamentals of neurology training, it's challenging to also stay current with exciting advances. This task is particularly daunting when one considers that there are well over 100 neuroscience journals. The challenge of staying up to date does not disappear after residency and fellowship because lives and work remain busy. For the neurologist, any failure to stay current can have negative consequences on patient care. In response to this challenge, there are a few fee-based services that provide reviews, usually in print, of recent neurology literature, but downsides of these services include cost and the difficulty in finding time even to read these publications.

With these issues in mind, about a year ago I was struck by the immense potential for podcasting to provide timely, free neurology literature updates. Podcasting $^{1}$ has many advantages over traditional communication media: 1) Podcasts allow listeners to hear recordings on demand, i.e., when and where the listener wants. 2) Podcast production is relatively inexpensive, which ob- viates any need for costs to be shifted to the listener (thus almost all podcast "subscriptions" are free). 3) Podcasts are digital and thus available online to anyone in the world with online access. 4) Podcasts are very userfriendly; one reason being that there are many podcast "aggregators," i.e., directories such as iTunes, that manage a listener's podcasts, searching and downloading the most recent podcasts to the listener's MP3 player, iPod, or desktop.

Podcasting has become exponentially more popular over the past year, with the most popular podcasts now enjoying approximately 2 million downloads per month. But much more growth is predicted, and it still should be considered an underutilized medium. For example, the percentage of Web users who downloaded a podcast in the month of June 2006 was only $6 \%$ of US adult Web users (approximately 9 million users), according to Nielsen Analytics. ${ }^{2}$ Perhaps this is because people do not realize that podcasts can be accessed directly from a desktop computer or still think of iPods as being only for music, and because so many of us (me included) are not tech-savvy and easily feel overwhelmed by the informational technology revolution. Regardless, there is no viable reason why free, on-demand digital audio will not become mainstream within the next few years.

Can we expect nothing but sunny skies for podcasting as a tool for medical education? Probably not, in large part because podcasts-more so than journals-are vulnerable to clouding of the distinction between infomercial and unbiased content. This is because medical audio (or video) podcasts work best when they discuss results or practice styles in general terms; the "fine print" of methodology and statistical analysis $-p$ values and the like-will almost certainly be left sitting on the sidelines (can you imagine listening to a table of data?). This will prevent critical analysis by the listener and shift even more responsibility on the podcast producers to provide content that is accurate and objective. Industry-influenced podcasts will likely not be transparent or even discernible as advertisement. One way to combat this would be for organizations, such as the American Association of Neuromuscular and Electrodiagnostic Medicine (AANEM) and the American Academy of Neurology, to participate in podcasting. Their imprimatur would allow for easy identification of objective podcasts. Furthermore, neurology podcasters should adopt the following rules: 1) each should have an editorial board that chooses articles only from peer-reviewed publications; 2 ) the podcast equiv-

From the Department of Neurology, University of Virginia, Charlottesville.

Disclosure: The author reports no conflicts of interest.

Received August 25, 2006. Accepted in final form November 27, 2006

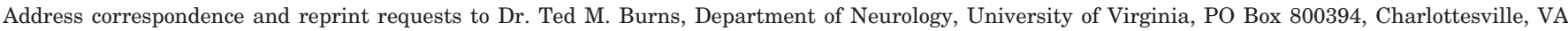
22908; e-mail: tmb8r@virginia.edu

Copyright () 2007 by AAN Enterprises, Inc. E19 
alent of journal supplements (which generally are not peer reviewed) should not be standard practice; 3) all editorial board members, discussants, interviewers, and interviewees should disclose potential conflicts of interest; 4) any advertisements or sponsorships should be clearly marked and not allowed to influence podcast content.

In the spring of 2006, I began working with the AANEM on the development of a bimonthly neuromuscular update podcast. We settled on an editorial board comprised of neuromuscular experts and agreed that we would interview only authors of peerreviewed articles that the AANEM podcast editorial board deemed to be instructive, informative, and/or interesting. We decided early on that rather than provide reviews of the published articles, we would instead use a format of interviewing authors. We thought this format (a discussion between two interviewers and one interviewee) would provide for a more interesting podcast than a podcast comprised simply of spoken reviews. The AANEM has supported this endeavor because of their commitment to medical education. We posted our first podcast, "AANEM Presents Nerve and Muscle Junction" (http://www. aanem.org/education/podcast/ index.cfm), in late August 2006. I urge residents and fellows in neurology training programs to listen to our podcast and adopt it as one method for keeping up to date in the neuromuscular world. I also urge residents and fellows to tell colleagues and mentors of the educational potential of podcasting but also to discuss the vulnerability of podcasting to be abused in order to market a product. The potential for podcasting for medical education will only be reached if physicians participate in the development and surveillance of this exciting new medium.

\section{References}

1. Wikipedia. Available at: http://en.wikipedia. org/wiki/Podcasting.

2. Nielsen Media Research. New York. Available at: http://www.nielsenmedia.com/nc/ portal/site/Public. 


\title{
Neurology
}

\author{
The forecast for podcasts: Sunny skies but not necessarily with clear visibility \\ Ted M. Burns \\ Neurology 2007;68;E19-E20 \\ DOI 10.1212/01.wnl.0000259068.95721.dc
}

This information is current as of April 9, 2007

\section{Updated Information \& Services}

Citations

Subspecialty Collections

Permissions \& Licensing

Reprints including high resolution figures, can be found at: http://n.neurology.org/content/68/15/E19.full

This article has been cited by 6 HighWire-hosted articles: http://n.neurology.org/content/68/15/E19.full\#\#otherarticles

This article, along with others on similar topics, appears in the following collection(s):

All Education

http://n.neurology.org/cgi/collection/all_education

Methods of education

http://n.neurology.org/cgi/collection/methods_of_education

Information about reproducing this article in parts (figures,tables) or in its entirety can be found online at:

http://www.neurology.org/about/about_the_journal\#permissions

Information about ordering reprints can be found online:

http://n.neurology.org/subscribers/advertise

Neurology ${ }^{\circledR}$ is the official journal of the American Academy of Neurology. Published continuously since 1951, it is now a weekly with 48 issues per year. Copyright. All rights reserved. Print ISSN: 0028-3878. Online ISSN: 1526-632X.

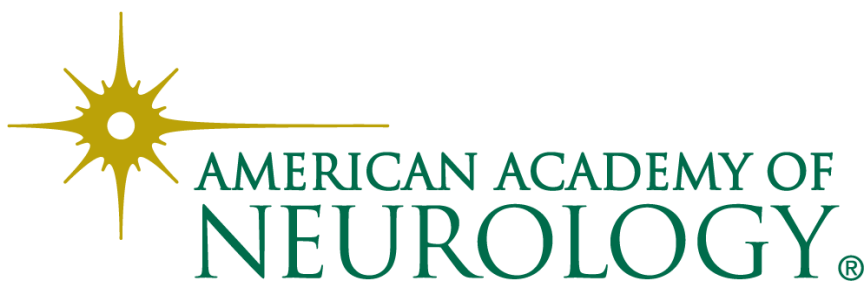

